\title{
Racial Categories in Medical Practice: How Useful Are They?
}

\section{Citation}

Braun, Lundy, Duana Fullwiley, Anne Fausto-Sterling, Evelynn M. Hammonds, Alondra Nelson, William Quivers, Susan M. Reverby, and Alexandra Shields. 2007. Racial categories in medical practice: How useful are they? PLoS Medicine 4, no. 9: 1423-1428.

\section{Published Version}

http://dx.doi.org/10.1371/journal.pmed.0040271

\section{Permanent link}

http://nrs.harvard.edu/urn-3:HUL.InstRepos:3008241

\section{Terms of Use}

This article was downloaded from Harvard University's DASH repository, and is made available under the terms and conditions applicable to Other Posted Material, as set forth at http:// nrs.harvard.edu/urn-3:HUL.InstRepos:dash.current.terms-of-use\#LAA

\section{Share Your Story}

The Harvard community has made this article openly available.

Please share how this access benefits you. Submit a story.

\section{Accessibility}




\author{
Lundy Braun, Anne Fausto-Sterling*, Duana Fullwiley, Evelynn M. Hammonds, Alondra Nelson, William Quivers, \\ Susan M. Reverby, Alexandra E. Shields
}

\section{The Trouble with Race}

Is it good medical practice for physicians to "eyeball" a patient's race when assessing their medical status or even to ask them to identify their race? This question was captured in a 2005 episode of "House M.D.," Fox television's medical drama. In the episode, a black patient with heart disease refuses a hospital physician's prescription for what is clearly supposed to be BiDil, the drug approved by the United States Food and Drug Administration only for "selfidentified" African-Americans [1]. Dr. House, on seeing the patient for followup, insists on the same prescription. The patient again refuses, telling House, "I'm not buying into no racist drug, OK?" House, a white physician asks, "It's racist because it helps black people more than white people? Well, on behalf of my peeps, let me say, thanks for dying on principle for us." The patient replies, "Look. My heart's red, your heart's red. And it don't make no sense to give us different drugs."

Who is right here, House or his patient? And what does this episode tell us about the way race plays itself out in the physician-patient clinical encounter? What of clinical importance can be learned by making a quick racial assessment [2]? That an ACE (angiotensin-converting enzyme) inhibitor may not be effective? That screening for sickle cell anemia is a waste of time? Sorting patients by race may seem useful during a timeconstrained interview, but we argue that acting on rapid racial assessment can lead to missed diagnoses and inappropriate treatments.

Both historical evidence and contemporary genetic research suggest that "racial profiling" in medicine

The Essay section contains opinion pieces on topics of broad interest to a general medical audience. can lead to serious medical errors. Assessing risk through race is more problematic than its typical depiction in the media and in scholarly literature [3]. Some argue that race can stand in for human genetic variance until individualized genetic medicine is fully developed. But such a position produces a critical paradox: the rates of morbidity and death from particular diseases are not uniformly distributed among socially defined racial and ethnic groups throughout the world [4-6]. In order to monitor the success of attempts to address these health inequalities, we need to keep health records based on racial and ethnic categories. This is a descriptive use of ethnoracial categories. Descriptive statistics derived from population surveys using racial definitions based on self-identity, however, are not biological or attributive categories appropriate for individual treatment [7]. How should physicians treat individuals who present with a perceived race but who may not bear the average characteristics of a studied population, even while collecting data based on perceived race or ethnicity and qualifying individuals for clinical research trials $[8,9]$ ? This problem is illustrated in Box 1, which describes an "on the ground" dilemma of administering a drug to individuals who do not fit "standard" racial categories.

\section{From Census Categories to Research Plans}

Racial categories, with shifting meanings and culturally determined parameters, have always shaped medical practice and thinking, leading to vigorous debates about their use in epidemiology, public health, and medical research journals [10-17]. Throughout the 20th century, race had no standard definition in medical, epidemiological, or health services research [18-21]. In epidemiology, race vaguely referred to "persons who are relatively homogenous with respect to biologic inheritance" [18]. One survey of medical and epidemiological

Funding: This work was funded by the Robert Wood Johnson Foundation (DF), the Office of the Provost, Harvard University (EMH), the Social Science Research Fund Grant, Yale University (AN), the Mellon Faculty Renewal Fund, Wellesley College (SMR), and the National Human Genome Research Institute P20 Grant HG003400 (AES). None of the funders were involved in our decision to write and publish this paper.

Competing Interests: The authors have declared that no competing interests exist.

Citation: Braun L, Fausto-Sterling A, Fullwiley D, Hammonds EM, Nelson A, et al. (2007) Racial categories in medical practice: How useful are they? PLoS Med 4(9): e271. doi:10.1371/journal. pmed.0040271

Copyright: $\odot 2007$ Braun et al. This is an open-access article distributed under the terms of the Creative Commons Attribution License, which permits unrestricted use, distribution, and reproduction in any medium, provided the original author and source are credited.

Lundy Braun is with the Departments of Pathology and Laboratory Medicine and Africana Studies, Brown University, Providence, Rhode Island, United States of America. Anne Fausto-Sterling is with the Department of Molecular and Cellular Biology and Biochemistry, Program in Women's Studies, and is Chair of the Faculty Committee on Science and Technology Studies, Brown University, Providence, Rhode Island, United States of America. Duana Fullwiley is with the Department of Anthropology and African and African American Studies, Harvard University, Cambridge, Massachusetts, United States of America. Evelynn M. Hammonds is Senior Vice Provost for Faculty Development and Diversity, and is with the History of Science and of African and African American Studies programs at Harvard University, Cambridge, Massachusetts, United States of America. Alondra Nelson is with the Departments of Sociology and African American Studies, Yale University, New Haven, Connecticut, United States of America. William Quivers is with the Department of Physics, Wellesley College, Wellesley, Massachusetts, United States of America. Susan M. Reverby is with the Women's Studies Department, Wellesley College, Wellesley, Massachusetts, United States of America. Alexandra E. Shields is with the Harvard/MGH Center on Genomics, Vulnerable Populations and Health Disparities, Massachusetts General Hospital, Harvard Medical School, Boston, Massachusetts, United States of America.

The authors are members of the Race, Medicine, and Science Workshop, Cambridge, Massachusetts, United States of America. Authorship is listed in alphabetical order.

* To whom correspondence should be addressed. E-mail: Anne_Fausto-Sterling@brown.edu 


\section{Box 1. Grace's Dilemma}

"What should I do with my Cape Verdean patient?" insists Grace, a third-year medical student. "The clinical protocol for hypertension requires me to identify his race but I don't know how. Is he black or white? This man immigrated to the US at a young age. Is he now African American or should I consider his health needs from the perspective of his immigrant status?" The data on response to therapy seem to suggest that hypertension in blacks is somehow special, implying a separate genetic factor for blacks. But the enormous national differences in hypertension rates do not support this argument. African Americans suffer at rates 3.5 times those of Nigerians living in Africa, although African Americans experience only 0.75 the rates of Germans in Germany [79]. Which category matters more for Grace's patient, country of origin or social status in the adopted nation?

Physicians everywhere face similar dilemmas. In clinical research projects or in the clinic, the assignment of race assumes an equivalence between census categories and genetics embodied by patients. The large Cape Verdean population in New England resists any simple categorization. The inhabitants are the descendents of Portuguese colonists, former slaves, explorers, and sailors of various nationalities. We suggest that, as with Cape Verdeans, census race cannot be assumed to reflect a particular genetic make-up.

dictionaries found that well into the 1980s definitions assumed that race reflects "underlying genetic homogeneity" rather than (or even in addition to) shared social experience [22]. Few of the studies making claims for race controlled for socioeconomic status or lifestyle variables.

The embedding of legal and social practices into the "common sense" meaning of race in medical research has been developing for centuries [23]. In the last several decades, poorly defined racial categories became reified in biomedical research practices, in part because of the widespread use of US census categories [24]. Since 2001, NIH-funded researchers have been required to categorize study participants into the five racial or ethnic categories defined by US Office of Management and Budget Directive No. 15 (American Indian or Alaska Native, Asian, Black or African American, Native Hawaiian or other Pacific Islander, or White, and Hispanic/Latino or not Hispanic/ Latino) [25]. Thus, state-sanctioned but ill-defined categories of race have entered medical research and practice with the admirable intent of ensuring full racial and gender inclusion in clinical trials, but with unanticipated consequences for health outcomes [26].

Researchers rely on respondents' self-identification to collect data on race and ethnicity. Every research grant must report its study population in these terms, leading to their universal use in recruitment of research subjects.
It thus becomes almost "natural" to use these same variables in the subsequent analysis and theoretical framing of the research, even though there is nothing particularly "natural" about the census categories. While the Office of Management and Budget's categories dominate researchers' analyses of human differences in disease, granting agencies' regulations do little to clarify the extent to which racial and ethnic categories are intended to capture biological, cultural, or social dimensions of human diversity. The US Institute of Medicine, for example, holds that race should not be considered a biological reality, but rather "a construct of human variability based on perceived differences in biology, physical appearance, and behavior" [27]. And self-identities are given reality by the very categories we use to describe them $[28,29]$.

Over the past several years, editors at leading medical and scientific journals have promoted a much needed dialogue among researchers and practitioners on the meaning of racial categories [30-40]. The current situation, however, remains confusing. As genetic findings assume an increasingly prominent place in biomedical research, some have concluded that selfidentified race/ethnicity, routinely collected in biomedical research studies, is a reasonable proxy for genetic homogeneity and may lead to important insights into health disparities [36,41-43]. Others, citing the genetic heterogeneity within self- identified groups [44-46], argue that race should not be used in genetic research [47-50]. A related perspective comes from those who argue that selfidentified racial/ethnic categories may be practical for recruitment into studies, but should not be used in genetic analyses, given that more biologically precise measures of human genetic heterogeneity are available $[17,51]$. A recent study of geographic patterns of genetic variation, for example, found that "commonly used ethnic labels are both insufficient and inaccurate representations of the inferred genetic clusters, and that drug-metabolizing profiles... differ significantly among the clusters" [52].

\section{Racial Categories Are Historical, Not Natural}

Historically created racial categories often carry hidden meanings. Until 2003 medical reports were cataloged in PubMed/MEDLINE and in the old Surgeon General's Index Catalogue using 19th century racial categories such as Caucasoid, Monogolid, Negroid and Australoid [53]. Originally suggesting a scale of inferiority and superiority, today such groupings continue to connote notions of human hierarchy $[27,54,55]$. More importantly, PubMed's newer categories, such as continental population group and ancestry group, merely overlay the older ones. Assuming that "African" origin can capture the complexity of migrations, artificial boundaries, and gene drift is scientifically unsupportable. So too is continued use of the concept of Caucasian (meaning from the central Asian countries surrounding the Caucus Mountains) to emphasize the similarities between disparate European groups rather than their population substructures or variations.

Racial definitions are historically and nationally specific. In her comparison of the history of racial categories in the US and Brazilian census from the late 18th century to the present, political scientist Melissa Nobles demonstrated that categories emerge and are deployed in different ways over time [56]. For example, during the mid-19th to the early 20 th centuries, at the height of US anxiety about "miscegenation," categories such as "mulatto" were vehicles for expressing and containing cultural anxiety about 
racial purity. Bolstered by scientific ideas about race, data collected on the numbers of "mulattoes" were shaped by the desire to prove that "hybrids" would die out.

Another example of the creation and stabilization of racial categories occurred in the mid-20th century under the apartheid government in South Africa. Obsessed with racial purity, the nationalist government passed the first Population Registration Act in 1950, which defined three groups-coloured, white, and native. According to the Act, a “'coloured person' means a person who is not a white person, or a native...'native' means a person who in fact is or is generally accepted as a member of any aboriginal race or tribe of Africa... 'white person' means a person who in appearance obviously is, or who is generally accepted as a white person, but does not include a person who, although in appearance obviously a white person, is generally accepted as a coloured person" [57].

Over the next 30 years, however, numerous amendments attempted to harden those boundaries. By 1967, the definition of a white person was extended to include "his habits, education and speech and deportment and demeanor in general" [58]. Coloured became a residual category, comprised of any person who could not be neatly assigned to one of the two main racial groups. In this definition, as with racial categories in both the United States and Brazil, cultural, class, and biological aspects of human variability are confounded. Since the 1994 dismantling of the apartheid state, racial or "population" categorization remains a subject of discomfort and public debate [59-61]. Categories such as white/European, African, coloured, and Asian, nonetheless, are still widely used in health care settings and in studies of genetic predisposition to disease in South Africa. Differing local conventions in racial categorization present difficulties in transnational collaborative research and peer review in international publications. South African researchers, for example, may feel pressured to employ categories that make no sense in their context (A. Mall, personal communication).

In the early 20th century in the United States, shades of blackness were assumed to affect medical outcomes. This view generated supposed facts

\section{Box 2. The Future of Research on Race and Health Disparities}

Race-related differences in health outcomes can be analyzed at the societal, individual, cellular, and subcellular levels. Studies focusing exclusively on one level often lose track of inter-level connections. Two research groups exemplify efforts to integrate research on health disparities at the level of cellular effects (e.g., on tumor production and growth), of societal level events (e.g., social support or toxin exposure), and individual life history events (e.g., reproductive history, stress, diet).

Epidemiologist Nancy Krieger [80-82] applies the concept of embodiment to an understanding of how the social effects of racism and social inequality become symptoms [83] and illnesses that manifest as racially related health disparities (on embodiment, see also Fausto-Sterling, 2005 [84]). Krieger understands embodiment to be a multilevel phenomenon that serves as "an antonym to disembodied genes, minds and behaviors" [82]. Similarly, Masi and Olopade [85] propose a multilevel perspective on racial and ethnic disparities in breast cancer. Their model illustrates how the dynamics of societal and individual events over the life cycle can have specific cellular outcomes resulting in neoplasms with particular cellular characteristics. To the extent that societal and individual events vary systematically with social race, biological outcomes may result from social inequalities. The key to future understandings of health disparities lies in using frameworks such as those proposed by Krieger and Masi and Olopade to design and interpret research at every level, from the social to the cellular.

(the "fact" that blacks have lesser lung function, for example). Once a "fact" was linked to race rather than unhealthy living and working conditions, it resisted further challenge and became part of clinical judgments. For example, until the widespread use of penicillin, induced malarial fevers were used to treat neurosyphilis and differing malarial strains were deployed based on racial lines [62,63]. As one key 1932 textbook explained, black resistance to tertian malaria could be overcome "the lighter or closer to the Caucasian the particular Negro is" $[64,65]$. None of the texts explained how to measure color or why it was assumed that blacks, unlike whites, would be exposed to differing malarial strains, as if the mosquitoes respected residential segregation and could not cross a road or tracks. Even though retrospective data made it clear that syphilis was more likely to attack the cardiovascular rather than the neurological system in both blacks and whites, it was assumed that since African Americans did more labor than "brainwork," they were more at risk for cardiovascular complications. Black cardiovascular deaths, in turn, were often labeled syphilitic in origin without the benefit of autopsy, or misread when postmortems were done (S. M. Reverby, work in progress).

\section{"Knowing" Race: From Research Plans to Individual Treatment}

But the debate remains. Even given the history of the (mis) use of racial categories, are they nevertheless useful in the physician's office? Does a quick administrative assessment of race help to diagnose a presenting ailment, or accurately assess future risk of illness? Environmental exposures, family histories, the stress of dealing with racism, access to and quality of care may be left unexamined if a physician simply diagnoses "race" [66]. In the United States a rule that assumes "one drop" of African blood defines an individual as African American [28] seems to prevail [67]. Presented with a black patient, in the face of medical uncertainty, rather than applying individual analysis the doctor can fall back upon general statements that derive from population studies, such as "You should get tested for glaucoma because you are African American and African Americans have a higher rate of glaucoma."

A dark-skinned, curly-headed person who identifies as African American may, indeed, have much in his or her history and upbringing to justify that identification. But he or she may also have a white grandparent and several Cherokee ancestors. Thus, returning to the example of glaucoma, it is more important to know a patient's family history than to assess his or her race. And collecting family history ought to mean not only compiling a list of which diseases family members have, but making some attempt to assess common (familial) habits such as diet and life experiences (e.g., first- versus second-generation immigrants, living 
conditions, or same versus widely varied work experience and geographical locations). Similarly, when the history of passing for white is ignored, those who identify themselves as "white" are assumed to have no ancestral "black blood." Finally, immigration patterns constantly change. A "black" person walking into a Boston, Massachusetts clinic could easily be the child of a recent immigrant from Ethiopia or Brazil who has a genetic makeup as well as cultural and environmental exposures that differ significantly from the descendents of 19 th century US slaves from the western coast of Africa [68,69].

Once race is presumed, the ways in which multiple genetic inheritances interact with the environment within that individual seem to disappear (see Box 2). Clinical clues can become invisible. Even with the relatively few diseases "known" to have a 1:1 relationship between a single mutant allele and a disease phenotype, reliance on a general idea of race can lead to misdiagnosis. In a different American television series, ER, a "white" patient with sickle cell anemia was misdiagnosed because the condition is known as a "black" illness. Sickle cell anemia (homozygous HbSS) results from a genetic alteration affecting the hemoglobin protein. Its high prevalence in some populations bespeaks their historical burden of falciparum malaria. The simple gene change responsible for sickle hemoglobin spans the continent of Africa and beyond. Its prevalence in the sub-Saharan region ranges between $10 \%$ to $40 \%$ [70]. Within even smaller geographical areas this diversity is also apparent. In the tiny West African country of The Gambia, the Mandinka people have an extremely low incidence at $4 \%$, the Wolof are nearly on par with black Americans at $14 \%$, and the more socially endogenous Fula hover just below 30\% [71]. Nonetheless, in a clinical encounter in North America, where census category definitions of race prevail, these groups and their descendents would, most likely, occupy the category "Black or African American.” Moreover, some of the highest rates in the world are found in India, with rates of $33 \%$ and $35 \%$ in the Pardhan and Oktar people, respectively [72]. Sickle cell disease is thus not "race-bound."
So what is the practicing physician to do? In the case of sickle cell disease, it would be best to work from symptoms rather than racial assumptions, and to enquire about geographic ancestry since sickle cell is more prevalent in populations from the Mediterranean region, sub-Saharan Africa, and the Indian subcontinent [70].

\section{Is Cultural Competency the Answer?}

Clinicians will make better educated patient evaluations if they familiarize themselves with the history of the particular communities they serve. For the clinical encounter, the cultural competency paradigm is sometimes offered as a tool for improving quality of care. Cultural competency advocates have spurred curricular reform so that clinicians in training learn to be attentive to cross-cultural issues. A cultural competency paradigm has recently been suggested as a powerful tool in the arsenal to combat the prevalence of racial and ethnic health disparities [73]. However, when not thoughtfully executed, the cultural competency paradigm can abet the simplistic thinking on race it seeks to address. On the one hand, this perspective brings greater attention to the attitudes and behaviors that patients may bring to the clinical encounter. On the other hand such cultural stereotyping could produce poor health outcomes if the clinician is more attentive to what he or she thinks they know about this "type" of patient than to the individual before them [74].

\section{Race in the Era of Individually Tailored Treatment}

Medical researchers want tools that will allow physicians to understand how the individual biosocial system represented by a patient standing before them has either produced symptoms, or has a certain future likelihood of doing so. Whether or not the recent announcement of a $\$ 10$ million cash award for the first team to sequence 100 genomes in 10 days will get us closer to individual genomic medicine remains to be seen [75]. But in the meantime, race remains a social characteristic of populations and it is inappropriate to use it as a central diagnostic tool for an individual patient.
The case of BiDil, the drug the fictional Dr. House prescribed to his skeptical African American patient, stands as a cautionary tale [76]. Depending on how the age-specific morbidity data on heart disease are read, the case for the urgency of additional treatments for African Americans can be made. Those advocating for BiDil argued that the dangers of the disease are so grave that there was a moral necessity for a race-specific drug, while others found the statistical case for differential morbidity to be unconvincing [77]. By primarily relying on a clinical trial that only included black men and women, claims were made that the drug worked for those who defined themselves as African American. Further, earlier studies that purported to show that ACE inhibitors-another medication for heart failure and an alternative to the active therapies in BiDil-did not work as well on blacks failed to acknowledge that this was not true for all black people in the study [51]. Other researchers who work on drug metabolizing enzymes have argued bluntly that "skin pigment is a lousy surrogate for drug-metabolism status or most any aspect of human physiology " [51].

BiDil's real impact may therefore be less on actual patient care (since physicians are being encouraged to use the drug "off-label" for anyone they please) and more on the fact that the US government gave its stamp of approval for what bioethicist Sandra Soo-Jin Lee labels "racial profiling in biomedicine" [78]. Although the drug may reify race, this may not be a useful guide to determine who needs it. In the end Dr. House may be right about how medicine is practiced and how drugs are marketed, but his patient understands more about the underlying biology.

\section{Thoughts for the 10-Minute Clinical Encounter}

Improved medical training about race can sharpen diagnostic skills. Cultural competency instruction should be modified to include information on the history of racial categories, current controversies about their biological significance, and the limits of their utility. A teaching unit on race would also contrast the differences between race as a population concept with 
its meaning when applied to the lives of individuals. In this context it would be appropriate to teach about geographical variations in specific allele frequencies for genes linked to particular disease processes, as well as the cultural practices, historical trends, and environmental conditions that favor their prevalence or not.

Physicians face huge demands for time efficiency and product output, often being called upon to process as many as six patients per hour. No wonder that rapid racial assessment is an attractive means to figure out what to do with a presenting patient. But we argue that even if there are short cuts for the medical interview, race is not a good one. There is, in the end (in addition to noting physical symptoms), no substitute for an inquiry into family history, an assessment of current circumstances, and knowledge about the biological and cultural histories of specific populations serviced by a particular treatment center.

\section{What Is To Be Done?}

In the long run, the problem of whether or how to use race as a diagnostic aid and research category requires an international consensus meeting with representatives from all the biomedical fields. Such a meeting should be organized by the US National Institutes of Health, the World Health Organization, and other international health institutes. In the short run, the National Institutes of Health needs to re-examine its race-based research rules, weighing the balance between attempting to include minority populations in our health care system, on the one hand, without forcing us into a misconstrual of race as biology on the other. Medical courses also need to improve the teaching of the complexities of using race in the clinic. The overall goal of such an effort would be to make clear that "For meaningful statements to be made about health disparities, careful consideration must be given to the way in which race and ethnicity are conceptualized, the choice of definition categories, and the way in which individuals are assigned to categories" [66]. Anthropologist Michael Montoya's distinction between using ethnoracial categories in a descriptive mode, to document progress in the health status of populations, but not using basically social categories to produce biological attribution of causes will be an essential part of this effort [7]. In the end we have to be able to answer the patient's question-if all hearts are red then why do we need different drugs for different individuals based on race? To provide the best health care we must be able to say why and when race matters and why and when it doesn't.

\section{Acknowledgments}

The authors would like to thank Jon Beckwith for helpful discussions and comments on this manuscript. Mae Clarke provided essential assistance in organizing the footnotes scattered among eight collaborators. We also acknowledge the contributions of participants in the Race, Medicine, and Science Workshop over the past nine years.

\section{References}

1. Witten M (2005) Humpty Dumpty. House MD Fox Television. Aired September 27, 2005. Available: http://www.twiztv.com/scripts/ house/season2/house-203.htm. Accessed 17 August 2007

2. Garcia R (2003) The misuse of race in medical diagnosis. Chron High Educ 49: B15.

3. Hacking I (2006) Genetics, biosocial groups and the future of identity. Daedalus 51: 81-95.

4. Papas G, Queen S, Hadden W, Fisher G (1993) The increasing disparity in mortality between socioeconomic groups in the United States, 1960 and 1986. New Engl J Med 329: 103-109.

5. Haynes MA, Smedley BD, editors (1999) The unequal burden of cancer: An assessmen of NIH research and programs for ethnic minorities and the medically underserved. Washington (D. C): National Academy Press.

6. Banks J, Marmot M, Oldfield Z, Smith JP (2006) Disease and disadvantage in the United States and in England. JAMA 295: 2037-2045.

7. Montoya MJ (2007) Bioethnic conscription: Genes, race, and mexicana/o ethnicity in diabetes research. Cultural Anthropology 22: 94-128

8. Warren P, Tomaskovic-Devey D, Smith W, Zingraff M, Mason M (2006) Driving while black: Bias and racial disparity in police stops. Criminology 44: 709-738.

9. Fiske ST (2005) This old stereotype: The pervasiveness and persistence of the elderly stereotype. J Soc Issues 6: 267-285.

10. Cooper R, Williams DR (1986) The biological concept of race and its application to public health epidemiology. J Health Polit Policy Law 11: 96-116.

11. LaVeist TA (1994) Beyond dummy variable and sample selection: What health services researchers ought to know about race as a variable. Health Serv Res 29: 1-16.

12. Muntaner C, Nieto FJ, O'Campo P (1996) The bell curve: On race, social class, and epidemiologic research. Am J Epidemiol 144: 531-536.

13. Freeman H (1998) The meaning of race in science-Considerations for cancer research. Cancer 82: 219-225.

14. Krieger N (2003) Does racism harm health? Did child abuse exist before1962? On explicit questions, critical science, and current controversies: An ecosocial perspective. Am J Public Health 93: 194-199.

15. Kaufman JS, Cooper RS (2001) Commentary: Considerations for use of racial/ethnic classification in etiologic research. Am J Epidemiol 154: 291-298.

16. Duster $\mathrm{T}$ (2005) Race and reification in science. Science 307: 1050-1051.
17. Shields AE, Hammonds EM, King PA, Lerman C, Rapp R, et al. (2005) The use of race variables in genetic studies of complex traits and the goal of reducing health disparities: A transdisciplinary perspective. Am Psychol 60: 77-103.

18. Jones C, LaVeist T, Lillie-Blanton M (1991) "Race" in epidemiologic literature: An examination of the American Journal of Epidemiology, 1921-1990. Am J Epidemiol 134: 1079-1084.

19. Kreiger N, Rowley DL, Herman AA, Avery B, Phillips MT (1993) Racism, sexism, and social class: Implications for studies of health, disease, and well being. Am J Prev Med 9 (Suppl 6): 82-122.

20. Williams DR (1994) The concept of race in health services research. Health Serv Res 29: 216-274.

21. Oppenheimer G (2001) Paradigm lost: Race, ethnicity, and the search for a new population taxonomy. Am J Public Health 91: 1049-1055.

22. Williams DR (1997) Race and health: Basic questions, emerging directions. Ann Epidemiol 7: 322-333.

23. Epstein S (2007) Inclusion: The politics of difference in medical research. Chicago: University of Chicago Press. 413 p.

24. United States Code (1993) National Institutes of Health Revitalization Act of 1993. Public Law 103-43 \$§131-151, 107, Stat 122, 133-140. Codified as amended at 42 USC $§ \S 283-290$ (2004).

25. National Institutes of Health (2001) NIH policy and guidelines on the inclusion of women and minorities as subjects in clinical research. Amended October 2001. Available: http:// grants.nih.gov/grants/funding/women_min/ guidelines_amended_10_2001.htm. Accessed 17 August 2007.

26. Epstein S (2004) Bodily differences and collective identities: The politics of gender and race in biomedical research in the United States. Body and Society 10: 183-203.

27. Institute of Medicine (2003) Unequal treatment: Confronting racial and ethnic disparities in health care. Available: http://www.nap.edu/openbook. php?isbn=030908265X. Accessed 20 August 2007.

28. Wright L (1994) One drop of blood. The New Yorker. Available: http://www.lawrencewright. com/art-drop.html. Accessed 20 August 2007.

29. Bowker G, Leigh SS (1997) Sorting things out: Classification and its consequences. Cambridge (MA): MIT Press. $377 \mathrm{p}$.

30. Council of Biology Editors, Style Manual Committee (1994) Scientific style and format: The CBE manual for authors, editors, and publishers. 6 th edition. Cambridge: Cambridge University Press. 825 p.

31. Editor (2000) Census, race and science. Nat Genet 24: 97-98.

32. Bhopal R, Donaldson L (1998) White, European, Western, Caucasian, or what? Inappropriate labeling in research on race, ethnicity, and health. Am J Public Health 88 1303-1307.

33. Schwartz RS (2001) Racial profiling in medical research. N Engl J Med 344: 1392-1393.

34. Wood AJ (2000) Racial differences in the response to drugs-Pointers to genetic differences. N Engl J Med 344: 1394-1396.

35. [No authors listed] (2001) Genes, drugs, and race. Nat Genet 29: 239-240.

36. Burchard EG, Ziv E, Coyle N, Gomez SL, Tang $\mathrm{H}$, et al. (2003) The importance of race and ethnic background in biomedical research and clinical practice. N Engl J Med 348: 1170-1175.

37. Cooper RS (2003) Race, genes, and healthNew wine in old bottles? Int J Epidemiol 32: 23-25.

38. Karter AJ (2003) Commentary: Race, genetics, and disease-In search of a middle ground. Int J Epidemiol 32: 26-28. 
39. Ellison GTH (2005) Population profiling and public health risk: When and how should we use race/ethnicity? Crit Public Health 15: 65-74.

40. Braun L (2006) Reifying human difference: The debate on genetics, race, and health. Int J Health Serv 36: 557-573.

41. Sankar P, Cho MK, Condit CM, Hunt LM, Koenig B, et al. (2004) Genetic research and health disparities. JAMA 291: 2985-2989.

42. Risch N, Burchard E, Ziv E, Tang H (2002) Categorization of humans in biomedical research: Genes, race and disease. Genome Biol 3: comment2007. E-pub 1 July 2002.

43. Tang HT, Quertermous T, Rodriguez B, Kardia SL, Zhu X, et al. (2005) Genetic structure, self-identified race/ethnicity, and confounding in case-control association studies. Am J Hum Genet 76: 268-275.

44. Baum BD (2006) The rise and fall of the Caucasian race: A political history of racial identity. New York: New York University Press. $352 \mathrm{p}$.

45. Bauchet M, McEvoy B, Pearson LN, Quillen EE, Sarkisian T, et al. (2007) Measuring European population stratification with microarray genotype data. Am J Hum Genet 80: 948-956.

46. Fullwiley D (2007) The molecularization of race. Sci Cult 16: 1-30

47. Cooper RS, Kaufman JS, Ward R (2003) Race and genomics. N Engl J Med 348: 1166-1170.

48. Jackson F (1993) Evolutionary and political economic influences on biological diversity in African Americans. J Black Stud 23: 539-540.

49. King RC (2000) Racialization, recognition, and rights: Lumping and splitting multiracial Asian Americans in the 2000 Census. J Asian-Am Stud 3.2: 191-217.

50. Tishkoff S, Kidd K (2004) Implications of biogeography of human populations for 'race' and medicine. Nat Genet 36(11 Suppl): S21-S27.

51. McLeod HL (2001) Pharmacogenetics: More than skin deep. Nat Genet 29: 247-248.

52. Wilson JF, Weale ME, Smith AC, Gratrix F, Fletcher B, et al. (2001) Population genetic structure of variable drug response. Nat Genet 29: 265-269

53. Sankar P (2003) MEDLINE definitions of race and ethnicity and their application to genetic research. Nat Genet 34: 119

54. Sankar P, Cho MK (2002) Toward a new vocabulary of human genetic variation. Science 298: 1337-1338.

55. Painter N (2003) Why white people are called 'Caucasian.' Proceedings of the Fifth Annual Gilder Lehman Center International Conference at Yale University. Available: http://www.yale.edu/glc/events/race/Painter. pdf. Accessed 20 August 2007.
56. Nobles M (2000) Shades of citizenship: Race and the census in modern politics. Palo Alto (CA): Stanford University Press. 248 p.

57. Population Registration Act, Act No. 30 of 1950, Republic of South Africa, Government Gazette.

58. Population Registration Act, Act No. 64 of 1967 Republic of South Africa, Government Gazette.

59. Ellison GTH, de Wet T, Ijsselmuiden CB, Richter LM (1996) Desegregating health statistics and health research in South Africa. S Afr Med J 86: 1257-1262.

60. Ellison CTH, de Wet T (1997) The use of 'racial' categories in contemporary South African health research. S Afr Med J 87 1671-1679.

61. West ME, Boonzaier EA (1989) Population groups, politics and medical science. S Afr Med J 76: $185-186$.

62. Callis HA (1929) Comparative therapy in syphilis. Journal of the National Medical Association XXI: January-March. Reprinted in: Wesley CH (1977) Henry Arthur Callis, life and legacy. Chicago: Foundation Publishers. pp. 186-204.

63. Callis HA (1929) Primary syphilis. J Nat Med Assoc XXI April-June. Reprinted in: Wesley CH (1977) Henry Arthur Callis, life and legacy. Chicago: Foundation Publishers, pp.186-204.

64. Schamberg J, Wright CS (1932) Treatment of syphilis. New York: D. Appleton. 525 p.

65. Moore JE (1947) The modern management of syphilis. 2nd edition. Springfield: Charles C. Thomas Publishers. 717 p.

66. Kaplan JB, Bennet T (2003) Use of race and ethnicity in biomedical publication. JAMA 289: 2709-2716.

67. Omi M, Winant H (1994) Racial formation in the United States: From the 1960's to the 1990's. New York: Routledge. 226 p.

68. Lee J, Bean FD (2004) America's changing color lines: Immigration, race/ethnicity, and multiracial identification. Annu Rev Sociol 30: 221-242.

69. Roberts S (2005 February 21) More Africans enter U.S than in days of slavery. The New York Times. Available: http://www.nytimes. com $/ 2005 / 02 / 21 /$ nyregion/21africa.html?ex= $1266728400 \&$ en $=0$ ea $8084 a 4 c 263210 \&$ ei $=5088 \&$ partner=rssnyt. Accessed 20 August 2007.

70. World Health Organization (2006) Sickle-cell anaemia: Report by the Secretariat. Available: http://www.who.int/gb/ebwha/pdf_files/ EB117/B117_34-en.pdf. Accessed 20 August 2007.

71. Ackerman H, Usen S, Jallow M, Sisay-Joof F, Pinder M, et al. (2005) A comparison of casecontrol and family-based association methods:
The example of sickle-cell and malaria. Ann Hum Genet 69 (Pt 5): 559-565.

72. Kate SL (2001) Health problems of tribal population groups from the state of Maharashtra. Indian J Med Sci 55: 99-108.

73. Betancourt JR, Green AR, Carrillo JE, AnanehFirempong IO (2003) Defining cultural competence: A practical framework for addressing racial/ethnic disparities in health and health care. Public Health Rep 118: 293-302.

74. Kleinman A, Benson P (2006) Anthropology in the clinic: The problem of cultural competency and how to fix It. PLoS Med 3: e294. doi:10.1371/journal.pmed.0030294

75. Wade N (2006 October 5) \$10 million prize set up for speedy DNA decoding. The New York Times. Available: http://select.nytimes. $\mathrm{com} / \mathrm{search} /$ restricted/article?res=F50F12FD3 E540C768CDDA90994DE404482. Accessed 20 August 2007

76. Reverby SM (2006 April 16) "Special treatment:" BiDil, Tuskegee and the logic of race. Paper given at the MIT Conference on Race, Pharmaceuticals and Medical Technology.

77. Kahn J (2004) How a drug becomes 'ethnic': Law, commerce, and the production of racial categories in medicine. Yale J Health Policy Law Ethics 4: 1-46.

78. Lee S-JS (2005) Racializing drug design: Implications of pharmacogenomics for health disparities. Am J Public Health 95: 2135-2138.

79. Cooper RS, Wolf-Maier K, Luke A, Adeyemo A, Banegas JR, et al. (2005) An international comparative study of blood pressure in populations of European vs. African descent. BMC Med 3: 2 .

80. Krieger N (2005) Defining and investigating social disparities in cancer: Critical issues. Cancer Causes Control 16: 5-14.

81. Krieger N (2005) Stormy weather: Race, gene expression and the science of health disparities. Am J Public Health 95: 2155-2160.

82. Krieger N (2005) Embodiment: A glossary for epidemiology. J Epidemiol Community Health 59: 350-355.

83. Krieger N, Smith K, Naishadham D, Hartman C, Barbeau EM (2005) Experiences of discrimination: Validity and reliability of a self-report measure for population health research on racism and health. Soc Sci Med 61: 1576-1596.

84. Fausto-Sterling A (2005) The bare bones of sex: Part I, sex and gender. Signs 30: 14911428.

85. Masi C, Olopade O (2005) Racial and ethnic disparities in breast cancer: A multilevel perspective. Med Clin North Am 89: 753-770. 
Copyright of PLoS Medicine is the property of Public Library of Science and its content may not be copied or emailed to multiple sites or posted to a listserv without the copyright holder's express written permission. However, users may print, download, or email articles for individual use. 